\title{
Faktor-Faktor Yang Mempengaruhi Minat Mahasiswa Dalam Berinvestasi Di Pasar Modal (Studi Kasus Pada Investor Pemula Yang Terdaftar di Galeri Investasi Universitas Warmadewa )
}

\author{
Kadek Linda Puspita Yani ${ }^{1}$, I Made Sara ${ }^{2}$, A.A.A. Erna Trisnadewi ${ }^{3}$ \\ Program Studi Akuntansi \\ Fakultas Ekonomi dan Bisnis Universitas Warmadewa, Bali, Indonesia \\ Email: lindapuspita217@gmail.com
}

\begin{abstract}
ABSTRAK
Pasar modal merupakan kegiatan yang berhubungan dengan penawara umum dan perdagangan efek, perusahaan publik yang berkaitan dengan efek yang diterbitkannya serta lembaga dan profesi yang berkaitan dengan efek. Tujuan dilakukan penelitian ini adalah untuk mengetahui faktor-fator yang mempengaruhi minat mahasiswa dalam berinvestasi di pasar modal. Sampel dalam penelitian ini adalah mahasiswa yang sudah berinvestasi di pasar modal melalui Galeri Investasi Bursa Efek Indonesia Universitas Warmadewa dan Mahasiswa Jurusan Akuntansi program S1 Angkatan Tahun 2016 sejumlah, dengan responden sebanyak 100 mahasiswa. Variabel dependen dalam penelitian ini adalah minat dan variabel independen dalam penelitian ini adalah modal investasi minimu, persepsi return, persepsi risiko, manfaat investasi dan motivasi. Metode penelitian yang digunakan adalah metode kuantitatif dengan data primer yang diperoleh dari data kuesioner yang diukur dengan skala likert. Teknik analisis data yang digunakan dalam penelitian ini adalah analisis regresi linier berganda. Data penelitian ini dikumpulkan dengan menggunakan kuesioner yang kemudian diolah dengan menggunakan bantuan program SPSS 25 . Hasil yang diperoleh dari penelitian ini adalah variabel modan investasi minimum (X1), persepsi return (X2), variabel persepsi risiko (X3), manfaat investasi (X4), dan motivasi (X5) berpengaruh positif dan signifikan terhadap minat mahasiswa dalam berinvestasi saham di pasar modal, variabel berpengaruh positif dan signifikan terhadap minat mahasiswa dalam berinvestasi di pasar modal.
\end{abstract}

Kata kunci: Minat, Modal Investasi Minimum, Persepsi Return, Persepsi Risiko Manfaat dan Motivasi.

\begin{abstract}
The capital market is an activity that deals with public offering and securities trading, public companies related to securities issued and institutions and professions related to securities. The purpose of this research is to find out the factors that influence students' interest in investing in the capital market. The sample in this study were students who had invested in the capital market through
\end{abstract}


the Indonesia Stock Exchange Investment Gallery, Warmadewa University, and accounting students in the 2016 bachelor program in 2016, with 100 students as respondents. The dependent variable in this study is interest and the independent variables in this study are your minimum investment capital, return perception, risk perception, investment benefits and motivation. The research method used is a quantitative method with primary data obtained from questionnaire data measured by a Likert scale. The data analysis technique used in this study is multiple linear regression analysis. The data of this study were collected using a questionnaire which was then processed using SPSS 25 . The results obtained from this study were the minimum investment variable (X1), return perception (X2), risk perception variable (X3), investment benefits (X4), and motivation (X5) have a positive and significant effect on students 'interest in investing in the stock market, variables have a positive and significant effect on students' interest in investing in the capital market.

Keywords: Interest, Minimum Investment Capital, Return Perception, Risk Perception and Motivation Risk.

\section{A. PENDAHULUAN}

Pasar modal memiliki peran yang bagus dalam perkembangan ekonomi nasional. Dimana semakin majunya khususnya bida perekonomian menyebabkan perkembangan Pasar Modal di Indonesia kian melesat. Maka perkembangan Indeks Harga Saham Gabungan 5 tahun terakhir. Menurut (Widianto, 2017) IHSG 5 tahun terakhir mulai dari tahun 2014 dengan nilai IHSG akhir tahun sebesar 5.226,95 dengan persentase 22,29\%, kemudian pada tahun berikutnya yakni tahun 2015, nilai IHSG akhir tahun mengalami penurunan yang cukup drastis hal ini nilai IHSG di Indonesia turun mencapai nilai 4.593,01 persentase penurunan mencapai $-12,13 \%$ dari tahun sebelumnya. Pada tahun berikutnya, yaitu tahun 2016 nilai IHSG akhir tahun kembali berangsur membaik dengan menyentuh level 5.296,71 dan persentase peningkatan mencapai 15,32\%, serta pada tahun 2017 nilai IHSG akhir tahun kian terus bertambah hingga mencapai nilai 6.355,65 dengan presentase peningkatan sebesar 19,99\%, sampai pada akhirnya di tahun 2018 nilai IHSG akhir tahun kembali merosot dengan nilai 6.194,50 dan peurunan presentase mencapai $-2,54 \%$.

Menurut Saliman (2016 : 228), pada hakikatnya pasar modal adalah sarana yang efektif dalam menggerakkandana masyarakat untuk selanjutnya 
dana tersebut disalurkan kapada kegiatan-kegiatan yang produktif. Dana masyarakat yang masuk kpasar modal merupakan dana atau investasi jangka panjang. Oleh karena itu upaya pemerinta dalam meningkatkan modal atau menghimpun modal dalam perekonomian dapat dilakukan melalui pasar modal, dalam arti bahwa masyaraka dimana mendapatan kelebihan dana dapat menginvestasikan dananya tersebut melalui pasar modal.

Tak bisa dipungkiri bahwa mahasiswa merupakan salah satu calon investor muda yang paling menarik karena telah memiliki dasar pengetahuan dasar investasi sejak memasuki dunia perkuliahan (Hermanto, 2017). Menurut kepala pengembangan wilayah Bursa Efek Indonesia (BEI) Khadafi dalam Republika.co.id (2018) BEI juga mengajak mahasiswa untuk terliba dalam pasar modal dengan menjadi investor,

karena pasar modal bukan semata milik investasi berskala besar atau merek yang sudah piawai selama bertahun-tahun. Dalam hal ini mahasiswa memiliki banyak potensi dan cara untuk terlibat aktif sebagai investorsalah satunya melalui fasilitas Galeri Investasi (GI) yang sudah tersebar di sejumlah perguruan tinggi di Indonesia. Dengan adanya galeri investasi Bursa Efek Indonesia (BEI ) diingunkan memberikan arti bagi semua pihak sehingga dengan informasi pasar modal tepat sasaran serta dapat memberikan manfaat yang optimal bagi mahasiswa, praktis ekonomi dan pengamat pasar modalmaupun masyarakat umum di daerah dan sekitarnya baik untuk kepentingan sosialisasi dan pendidikan/edukasi pasar modal maupun untuk kepentingan ekonomis atau alternati investasi (idx.co.id).

\section{B. TINJAUAN PUSTAKA}

1. Minat

Menurut Nandar (2018) Minat berkembang sebagai hasil dari suatu kegiatan dan akan menjadi sebab untuk digunakan kembali dalam kegiatan yang sama. Salah satu faktor yang mempengaruhi minat 
adalah faktor inner urge yaitu rangsangan yang datang dari lingkungn atau ruang lingkup yang sesuai dengan keinginan atau kebutuhan seseorang akan mudah menimbulka minat.

\section{Pasar Modal}

Pasar Modal dirumuskan bahwa yang dimaksud dengan bursa efek adalah pihak yang menyelenggarakan dan menyediakan sistem dan/atau sarana untuk mempertemukan penawaran jual beli efek pihak-pihak lain dengan tujuan memperdagangkan efek di antara mereka. Adapun yang dimaksud dengan efek adalah surat berharga.

3. Investasi

Investasi merupakan penegluaran penanam modal dimana guna membelii barang moda dan perlengkapan produksi guna menambah kemampuan produksi.

4. Modal Investasi Minimal

Menurut Hogan (2019:24), saat ini ada banyak perusahaan sekuritas yang menawarkan pembukuan rekening saham dengan dana hanya 100 ribu saja. Dimana membuat investasu lebuh mudah bagi masyarakat dari beraneka ragam golongan, dengan investasi yang kecil maka akan menumbuhkan mahasiswa investasi ke pasa modal.

5. Persepsi Return

Menurut Nandar (2018), pada konteks manajemen investasi, tingkat keuntungan investasi disebut sebagai return. Pada konteks manajemen investasi, perlu dibedakan antara return harapan dan return aktual atau yang terjadi. Return harapan merupakan tingkat return yang diantisipasi investor di masamendatang.

6. Persepsi Risiko

Menurut Jogiyanto (2014:308), risiko sering dihubungkan dengan penyimpangan atau deviasi dari outcome yang diterima dengan yang diharapkan. Risiko adalah tingkat potensi kerugian yang timbul karena perolehan hasil investasi yang diharapkan tidak sesuai dengan harapan investor.

7. Persepsi Manfaat Berinestasi

Persepsi manfaat investasi adalah anggapan seorang investor yang lebih 
mengacu pada keuntungan dalam pengelolaan keuangan pribadi maupun keluarga. Dengan adanya persepsi manfaat investasi investor akan memiliki anggapan bahwa berinvestasi di pasar modal akan dapat meningkatkan kondisi perekonomian keluarga.

\section{Motivasi Investasi}

Motivasi merupakan faktor investasi yang memberikan pengaruh besar terhadap minat seseorang dalam berinvestasi di pasar modal. Terdapat dua jenis motivasi, yakni Motivasi yang tumbuh dari dalam diri seseorang dikarenakan adanya kemauan diri untuk menggali informasi tentang investasi dan pasar modal sehingga seseorang akan berpikir untuk masa depannya. Dan motivasi yang tumbuh dari luar yaitu dorongandorongan berupa ilmu atau informasi yang diberikan oleh motivatormotivator yang berpengalaman terkait investasi dan pasar modal sehingga pikiran seseorang menjadi terbuka dan berpikir untuk masa depannya.

Adapun hipotesis dalam penelitian ini yaitu:

H1: Modal Investasi minimum Berpengaruh Positif Terhadap Perilaku Mahasiswa Untuk Berinvestasi di Pasar Modal.

H2: Persepsi Return Berpengaruh Positif Terhadap Perilaku Mahasiswa Untuk Berinvestasi di Pasar Modal.

H3: Persepsi Risiko Investasi Berpengaruh Positif Terhadap Perilaku Mahasiswa Untuk Berinvestasi di Pasar Modal.

H4: Manfaat Investasi Berpengaruh Positif Terhadap Perilaku Mahasiswa Untuk Berinvestasi di Pasar Modal.

H5: Motivasi Investasi Berpengaruh Positif Terhadap Perilaku Mahasiswa Untuk Berinvestasi di Pasar Modal

\section{METODE PENELITIAN}

Pada penelitian ini dilakukan di Universitas Warmadewa. Adupun objek peneliyian ini yaitu modal investasi minimal, persepsi return, persepsi risiko, 
motivasi dan manfaat investasi pada minat mahasiswa dalam berinvestasi di pasar modal Indonesia. Populasi angkatan tahun2016 Jurusan Akuntansi Program S1. Jenis data yang dipakai primes dan sekunder dan teknis analisis data uji analisis linear berganda.

\section{HASIL DAN PEMBAHASAN}

1. Pengujian Kualitas Data

Berdasarkan hasil uji validitas menyatakan bahwa semua variabel dependen menyatakan kolerasi antara butir-butir pertantaan dengan skor lenih dari 0,3 yang berarti bahwa butir pertanyaan pada variabel independen modal investasi minimum dinyatakan valid.

2. Uji Asumsi Klasik

Berdasarkan hasil uji normalitas menyatakan penelitian ini sebesar $0,200>0,05$ bahwa residual terdistribusi normal yang artinya asumsi dasar tentang kenormalan yang telah dipenuhi. Uji Multikolinearitas, terlihat bahwa nilai tolerance pada masing-masing variabel independen lebih dari 0,10 dan hasil dari Variance Inflation Factor (VIF) juga menunjukan nilai kurang dari 10. Maka dapat disimpulkan bahwa kelima variabel independen dalam persamaan model regresi bebas dari multikolonieritas. Uji heteroskedastisitas memiliki nilai > alpha 0.05 yaitu masing-masing sebesar $0.098, \quad 0.588, \quad 0.108, \quad 0.160$ dan 0.984 sehingga dapat disimpulkan bahwa data homoskedastisitas atau tidak mengalami masalah heteroskedastisitas.

3. Uji Analisis Linear Berganda

Berdasarkan hasil menyatakan $\mathrm{Y}=8,680+0,268 \mathrm{X}_{1}+0,144 \mathrm{X}_{2}+$ $0,129 \mathrm{X}_{3}+0,126 \mathrm{X}_{4}+0,165 \mathrm{X}_{5}$ yang artinya semua koefisien regresi berpengaruh terhadap perilaku mahasiswa dalam berinvestas.

4. Uji F

Berdasarkan uji ANOVA (Analysis of Variance) menyatakan bahwa dapat diketahui bahwa uji F memiliki nilai signifikansi sebesar 0.000 lebih kecil dari tingkat signifikansi 0,05. Artinya model regresi yang diestimasi 
mampu digunakan untuk menjelaskan pengaruh hubungan variabel bebas modal investasi minimum, persepsi return, persepsi risiko investasi, manfaat investasi dan motivasi investasi terhadap variabel terikat minat mahasiswa dalam investasi dengan kata lain secara simultan atau secara bersamaan variabel bebas modal investasi minimum, persepsi return,

persepsi risiko investasi, manfaat investasi dan motivasi investasi berpengaruh secara signifikan terhadap terhadap variabel dependen minat mahasiswa dalam investasi.

5. Uji t

Berdasarkan hasil uji menyatakan bahwa nilai $\mathrm{t}$ tabel pada tingkat signifikansi 0,05 dan derajat bebas $(\mathrm{df})$ adalah $\mathrm{df}=\mathrm{n}-\mathrm{k}-1=100-3-1=96$, sehingga diperoleh nilai t tabel sebesar 1.984. Dapat diketahui bahwa uji hipotesis dari masing-masing variabel independen terhadap variabel dependen. Dimana setiap kelima variabel memiliki nilai signifikan lebih kecil dari 0,05 yang artinya kelima variabel berpengaruh terhadap variabel independen.

\section{E. PENUTUP}

\section{Simpulan}

Berdasarkan hasil uji dan pembahasan yang dilakukan, dapat ditarik simpulan dalam penelitian ini, yaitu:

a. Modal investasi minimum berpengaruh positif dan signifikan terhadap minat mahasiswa untuk berinvestasi di pasar modal.

b. Persepsi return berpengaruh positif dan signifikan terhadap minat mahasiswa untuk berinvestasii pasar modal.

c. Persepsi risiko berpengaruh positif dan signifikan terhadap minat mahasiswa untuk berinvestasi di pasarmodal.

d. Manfat investasi berpengaruh positif dan signifikan terhadap minat mahasiswa untuk berinvestasi di pasar modal.

e. Motivasi berpengaruh positif dan signifikan terhadap 
minatmahasiswa untuk berinvestasi di pasarmodal.

\section{Saran}

Dimana saran yang bisa saya berikan yaitu bagi mashasiswa universitas warmadewa yaitu

1. Memperbanyak variabel modal minimum, persepsi return, persepsi risiko, manfat investasi dan motivasi. Variabel lain seperti fasilitas online, persepsi kemudahan, edukasi, psikografis, nilai tambah, kondisi ekonomis, pengetahuan investasi dan self eficacy, serta dapat memperbanyak indikator variabel. Selain itu dapat menambah metode lain seperti wawancara, untuk mengatasi kelemahan dalam metode kuesioner.

\section{DAFTAR PUSTAKA}

Bakhri, Syaeful, (2018), Minat Mahasiswa Dalam Berinvestasi Di Pasar Modal Indonesia, Syariah dan Ekonomi Islam, 10 (1): 146-157.

Gumiwang,Ringkang, (2018), Tipisnya Jumlah Investor PasarModal Indonesia, $\quad$ https://tirto.id/tipisnya-jumlah-investor-pasar-modalindonesiacHXg https://www.google.co.id/amp/s/amp.tirto.id/tipisnyajumlah-investor-pasar-modal-indonesia-cHXg, 22 Agustus 2019

Jogiyanto, (2007), Sistem Informasi Keperilakua, Edisi 1, Penerbit ANDI, Yogyakarta.

Rahayuda, Ketut, (2017), Metode Penelitian Bisnis, Cetakan Pertama, Penerbit Udayana University Press, Bali.

Sukirno, Sadono, (2016) Makro Ekonomi Teori Pengantar, Edisi Ke 3, Rajawali Pers, Jakarta.

Wibowo, Heru, (2018), Meningkatkan Investor Saham Melalui Edukasi Berkelanjutan. Diakses pada https://news.detik.com/kolom/d3948692/meningkatkan-investor-saham-melalui-edukasi-berkelanjutan, tanggal 22 Agustus 2019

Widianto, Arif. 2017. Sejarah Kinerja IHSG 10 Tahun. Diakses pada https://bolasalju.com/artikel/sejarah-kinerja-ihsg-10-tahun/, tanggal 26 Agustus 2019. 
Witakusuma, Etayana, Putu Sukma Kurniawan, dan Edi Sujana, (2018), Faktor-faktor Yang Mempengaruhi Perilaku Mahasiswa Dalam Berinvestasi Di Pasar Modal (Tinjau Empiris Pada Investor Pemula), eJurnal S1 Ak Universitas Pendidikan Ganesha, 9(2). 